\title{
Evaluating the performance of rural areas in improving entrepreneurship infrastructure for the development of rural entrepreneurship in Khalilabad city
}

\section{Evaluación del desempeño de las áreas rurales en la mejora de la infraestructura empresarial para el desarrollo del espíritu empresarial rural en la ciudad de Khalilabad}

\author{
Ayoub Akherati Ivari
}

PhD Student, Department of Geography and Rural Planning, Mashhad Branch, Islamic

Azad University, Mashhad, Iran

ORCID ID: https://orcid.org.0000-0003-4460-3965

\section{Hamid Jafari}

Department of Geography, Mashhad Branch, Islamic Azad University, Mashhad, Iran ORCID ID: https://orcid.org.0000-0002-2007-562X

\section{Mohammad Ali Ahmadian}

Department of Geography, Mashhad Branch, Islamic Azad University, Mashhad, Iran ORCID ID: https://orcid.org.0000-0003-3414-4371

Received 09-08-20 Revised 10-10-20

*Correspondence

Email: jafari1421@mshdiau.ac.ir
Accepted 12-12-20 On line 03-10-21

Cite as:

Akherati Ivari, A., Jafari, H., \& Ahmadian, A, M. (2021). Evaluating the performance of rural areas in improving entrepreneurship infrastructure for the development of rural entrepreneurship in Khalilabad city. Propósitos y Representaciones, 9 (SPE3), e1122. Doi:

http://dx.doi.org.10.20511.pyr2021.v9nSPE3.1122 


\section{Summary}

Entrepreneurship in order to generate income and employment is one of the most important tools for rural development and the present study has been prepared with the same purpose and as the evaluation of rural performance in improving entrepreneurship infrastructure for rural entrepreneurship development in Khalilabad city. The present research is applied in terms of purpose and in terms of descriptive-analytical method, which used library and field methods to collect information and a researcher-made questionnaire for field data. The sample population was randomly studied using Cochran's formula including 370 people in 23 villages of the city. The results obtained in the villages of the city show that the performance of rural villagers in Khalilabad city in order to develop rural entrepreneurship has been weak. The villages of the city, except for the development of public infrastructure (water, electricity, etc.) in other areas of entrepreneurial infrastructure have not performed well and have not been able to achieve the desired goals.

Keywords: Performance evaluation, Rural management, Rural entrepreneurship, Khalilabad city.

\section{Resumen}

El espíritu empresarial para generar ingresos y empleo es una de las herramientas más importantes para el desarrollo rural y el presente estudio ha sido elaborado con el mismo propósito y como la evaluación del desempeño rural en la mejora de la infraestructura empresarial para el desarrollo empresarial rural en la ciudad de Khalilabad. La presente investigación se aplica en términos de propósito y en términos de método descriptivo-analítico, que utilizó métodos de biblioteca y de campo para recolectar información y un cuestionario elaborado por investigadores para datos de campo. La población de la muestra se estudió aleatoriamente utilizando la fórmula de Cochran que incluyó a 370 personas en 23 aldeas de la ciudad. Los resultados obtenidos en las aldeas de la ciudad muestran que el desempeño de los pobladores rurales de la ciudad de Khalilabad para desarrollar el espíritu empresarial rural ha sido débil. Los pueblos de la ciudad, salvo el desarrollo de infraestructura pública (agua, electricidad, etc.) en otras áreas de infraestructura empresarial, no han tenido un buen desempeño y no han podido alcanzar las metas deseadas.

Palabras clave: Evaluación del desempeño, gestión rural, emprendimiento rural, ciudad de Khalilabad.

\section{Introduction}

Research is a systematic and logical process of finding answers to questions that are important to researchers in a scientific field. Scientific research always starts with a problem or problem and its goal is to find the answer to the problems using scientific methods. The first step in this direction is to solve the problem with a logical and plausible system. Express control. The most difficult step in the research process is to identify the issue under study (Ismaili and Biabangard, 2002: 6).

Today, one of the effective strategies in the comprehensive and self-sustainable development of rural areas is to use the participation and capabilities of the people, especially the villagers for the development of rural areas in all its dimensions and the most important tool to achieve this is the formation of organized non-governmental organizations. Based on the needs and abilities of different groups living in the village, in various and necessary issues, the local and indigenous environment is created in order to implement rural development programs. In recent years, Islamic 
councils and villages have been defined as village management and can help by attracting financial resources and matters by policy-making, management and implementation of various educational programs, development of necessary infrastructure, Provide this in the development of rural entrepreneurship (Hashemi et al., 2011: 93).

Entrepreneurship is one of the main axes and growth and development in any country as it is known as the engine of economic development in any country (Behmand, 2016: 1).

Villages are facing extensive changes and threats in the present era, so ensuring the survival of villages need new solutions and methods to deal with problems that lead to innovation, innovation, creation of products, processes and methods. New ones are very dependent (Khodabandeh Lou et al., 2014: 29).

Various studies in the world show that one of the most important goals of rural development in order to generate income, job creation and its most important mechanism and tool is entrepreneurship. Entrepreneurship reduces unemployment, increases productivity and creates job opportunities for other people and thus increases the income of villagers. Of course, it should be noted that entrepreneurship is not the only way to create jobs and increase the income of villagers, but it can be the best among other appropriate solutions. Existence of continuous support for rural entrepreneurs, development of appropriate contexts (in terms of social, cultural and economic infrastructure) in rural areas, encouragement of rural entrepreneurs, etc. can be entrepreneurship, a practical solution suitable for rural development goals, ie creating useful employment, Increase income and build participation and self-reliance of the villagers. Therefore, in order to empower, build capacity and increase the field of participatory activities in rural areas, it is necessary to study the factors and reasons affecting the success of rural people and the areas of increasing entrepreneurship to improve the economic situation of rural people in rural areas (Malashahi and Tabrizi Dokht Fard, 2014: 27).

Identifying barriers affecting the development of rural entrepreneurship can be helpful in recognizing the various dimensions related to rural entrepreneurship and barriers to employment in rural areas. In this way, the strengths and weaknesses in the field of rural entrepreneurship are identified, then it is possible to help the development of the country's villages by providing appropriate and local solutions (Kiakjouri et al., 2012: 5).

The experience of countries with high national income growth shows that one of the reasons for the success of these countries is that the managers of these countries have realized the role and importance of entrepreneurship in the development of the country. Entrepreneurship has advantages such as facilitating the marketing of products, creating employment, increasing the profits and capital of investors, providing social welfare, increasing exports, receiving foreign exchange, and so on. In recent years, the problems in the villages have increased the migration of villagers to the cities. One of the reasons is the existence of unemployment in rural areas. Entrepreneurship is an essential and important factor to achieve rural development as soon as possible and the existence of entrepreneurial managers creates sustainable employment in rural areas, so the new rural management has a special place in this regard (Saeedi, 2009: 171).

Khalilabad city with an area of 1120.3 square kilometers is one of the cities of Khorasan Razavi province which according to the results of the general population and housing census of 2016, had a population of 51701 people and 16684 households of which 32490 people (63\%) live in 27 villages and population density 28.8 People per square kilometer. Rural management, due to many interactions with villagers and the government can be through policy-making, management, implementation of various educational programs, development of necessary infrastructure, helping to attract financial resources, entrepreneurial behavior and attitude, creating cultural and social contexts of entrepreneurship, motivating entrepreneurship Among the villagers and such matters, play an essential role in the development of entrepreneurship in rural areas and provide 
the basis for the development of rural entrepreneurship (Khodabandeh Lou et al., 2014: 1). Therefore, the title of this study was "Evaluation of rural performance in improving entrepreneurial infrastructure for the development of rural entrepreneurship in Khalilabad city" and the main direction of this research is to answer this question:

What has been the performance of rural areas in the field of rural entrepreneurship development in the study area?

- The importance of the research topic

The topic the researcher chooses is important. This research may develop the researcher's knowledge about a specific branch of geography or fill the gap of his general geography knowledge (Haring, 1998: 27).

In the conditions of Iran today, the policies of uncontrolled urbanization and rural-urban transformation, the formation of severe social, economic and ecological damage in cities, especially metropolises, on the one hand, and the young and ready-to-work population to Along with villages empty of young people, on the other hand, it is necessary to review policies and strategies so that the village can fulfill its mission in providing food to citizens, preserving vital resources and natural ecosystems, and open conservation. The ability of urban people to do well. One of the ways experienced in the world in reviewing policies is to pay attention to entrepreneurship (Rokn al-Din Eftekhari and Sajasi Gheidari, 2014: 1). In recent centuries, with the rapid growth of industry and technology in the world, the backwardness of rural areas has become more apparent. Rural people have lower incomes than urban dwellers and have less social services, and rural people have become poorer and more vulnerable, which sometimes leads to their migration to cities. The reason for this is the geographical dispersion of villages, lack of economic efficiency to provide social services, unprofessional and specialized agricultural work, low productivity, limited water and soil resources in the face of population growth and lack of proper management of officials. Therefore, in order to eliminate the extreme poverty of rural areas, improve the level and quality of life of villagers and create employment and increase productivity, the strategy of rural entrepreneurship development has been adopted. Entrepreneurship as a new strategy in the development of rural areas due to the nature of high employment can create productive and permanent employment for villagers and temporary employment for the seasonal unemployed (Rokanuddin Eftekhari, 2013: 17-18), strengthen entrepreneurship and create a suitable environment For its development, it is one of the tools of economic development of countries, especially developing countries (Najafikani et al., 2015: 38). Villages are facing widespread changes and threats in the present era, so ensuring the continuity of life and survival of villages need new solutions and methods to deal with problems such as characterization, innovation, creation of products, processes and New methods depend a lot. To achieve this goal, managers must turn to maps that are tailored to changing environmental conditions. Therefore, rural development compared to the past, has a broader link with the concept of entrepreneurship (Azizi Demirchloo, 2012: 5).

One of the important fields in rural planning in Iran is to address the issue of rural employment in order to help maintain the population by solving the problems of rural employment, so any research that pays attention to this issue is important and the present title of this Ro is important. Theoretical

\section{Rural management}

Villages as special places with different lifestyles and activities compared to cities need a separate management model and in accordance with the economic, social and ecological conditions governing them (Rokn al-Din Eftekhari et al., 2007: 1). When it comes to rural management, management may not necessarily be well thought out and planned, in other words, the role of customs, habits and traditions in rural management is decisive. Management in its scientific sense 
and as it is mentioned in management books is not applied in Iranian villages and what exists is a kind of incomplete or quasi-management in which not all aspects and tasks of management are performed (Rahbar and Alavi, 2012). : 1).

\section{Entrepreneurship}

There are many different definitions of entrepreneurship. Some call it innovation, some equate it with risk-taking, some as market stabilizing and balancing force, and some equate it with creating a new business (or building a business based on a new idea) or development. Know the existing business. Entrepreneurship is the process by which an entrepreneur, with new ideas, identifying new opportunities and mobilizing resources, creates new businesses and companies, new and innovative organizations that are associated with accepting risk and risk and lead to the introduction of the product or It becomes a new service to the community. In the Encyclop dia Britannica, an entrepreneur is defined as a person who organizes and manages a business or economic institution and accepts the risks arising from it (Imanloo, 2013: 6). Entrepreneurship refers to the process of creating value through the combination of resources, using opportunity, which requires an entrepreneurial action and an entrepreneurial agent. (Tusi et al., 2014: 3-4).

Rural entrepreneurship

Rural entrepreneurship is the identification of new opportunities, innovation and creativity in agricultural and non-agricultural activities, innovation and creativity in land use and, in fact, the optimal and innovative use of rural resources for sustainable rural development (Zargoosh and Mozaffari, 2016: 7). According to Wartman, rural entrepreneurship is the creation of a new organization that introduces a new product or service or creates a new market or uses new technology in a rural environment. In another definition, rural entrepreneurship is an activity that gives people A villager helps to turn opportunities into profitable economic activities (Najafi Kani et al., 2015: 40).

\section{Research purposes}

The objectives of this research are as follows:

1- Recognizing the geographical features of a part of the land (study area);

2- Identifying issues and problems related to rural entrepreneurship;

3- Providing solutions and suggestions to solve the above-mentioned issues and problems in order to increase the living standards of the villagers and reduce migration.

\section{Research background}

In any research, for more information and the necessary effects on different aspects of the problem under study, the background and literature related to the research should be studied and the work of others in different aspects of the research problem or their experiences of similarities. Used in method and problem analysis (Sarukhani, 2008: 45).

Sajasi Gheidari (2010) in his book entitled "Rural Development with Emphasis on Entrepreneurship (Definitions, Perspectives and Experiences)" states that entrepreneurship as a process, phenomenon, system and strategy not only for the wider rural community in The land creates jobs, but by strengthening the skills and capacities of the local community, it transforms the income cycle in the villages into a new one, and can even produce the necessary goods and services that the market is so inclined to. Does not have to produce and service it.

Dadourkhani et al. (2011) in his article entitled "Analysis of the role of tourism in the development of entrepreneurial characteristics and entrepreneurship tendencies among rural youth (Case study: Kandovan village and Eskandan village of Osko city)" shows youth Kandovan village has higher 
entrepreneurial characteristics than the youth of Eskandan village and the reason is cultural interactions due to the presence of tourists as well as the formation of basic infrastructure and the existence of new opportunities due to tourism.

Hashemi et al. (2011) in his article entitled "Explaining the role of villages and Islamic councils in entrepreneurship development Case study: Bahabad, Yazd province" describes the role of local management in entrepreneurship development in the study area and the results of the research show It is that Islamic villages and councils have been relatively successful in developing rural entrepreneurship, and in the eyes of the people, the activities of entrepreneurs, local officials, village heads and councils provide the necessary grounds for rural entrepreneurship development, including entrepreneurial infrastructure, behavior and Entrepreneurial attitude has provided financial and economic resources and cultural and social factors, and the performance of villagers and councils in these cases has been acceptable and has led to the development of rural entrepreneurship.

Yaghoubi Farani et al. (2012) in his article entitled "Study and analysis of barriers and limitations of rural women entrepreneurship development in Iran" has identified the factors and barriers to rural women entrepreneurship development in Iran. The results indicate that the barriers and limitations of entrepreneurship of rural women fall into 9 categories, which are: individual conditions and characteristics, personality and behavior of rural women, family conditions and characteristics, knowledge and skills of rural women (education). , Experience, communication), cultural and social conditions (community, village), access to facilities and services needed by rural women (in the process of starting, running and developing a business), legal and legal factors, financial and economic factors, factors Institutional and organizational, geographical conditions and environmental factors (rural environment).

Heidarimakr and Naderianfar (2012) in their article entitled "Study of the role of the Relief Committee in the development of rural entrepreneurship (Case study: the area behind the water of Sistan)" state that due to the serious position of the Relief Committee in creating Suitable opportunities for small and medium-sized businesses across the country It seems that this sector can play a key role in developing entrepreneurship and eradicating poverty across the country. The results showed that a wide range of factors contribute to the poverty of the families of the relief committee, including the death of the spouse $04 \%$, drought $11 \%$, old age $53 \%$ and illness $14 \%$. The results also show that the creation of self-sufficiency plans and employment (entrepreneurship) has improved the living conditions of clients. Therefore, the activities of the Relief Committee in the area behind the water of Sistan have provided the necessary grounds for the development of entrepreneurship (attracting financial and economic resources) and has led to the development of rural entrepreneurship.

Sepahpanah (2012) in his article entitled "Rural management functions in entrepreneurship of farmers and villagers" has concluded that given that the economy of developing countries such as Iran is based on agricultural activities, Therefore, by using the right management method in the village, it is possible to create conditions for farmers to move towards entrepreneurship.

Azizi Demirchloo (2012) in his article entitled "Modern rural management is a solution to achieve rural entrepreneurship" has concluded that modern rural management using knowledge-based economy can have a very important impact on the success and survival of organizations To create value in the rural economy and increase employment in rural areas.

Yarfi and Murid (2012) in their article entitled "Study of the role of rural handicrafts in entrepreneurship and job creation to attract tourism" have concluded that there is a direct relationship between rural handicrafts and attracting tourism and entrepreneurship . Different activities each provide the ground for attracting tourists and tourism and ultimately will lead to poverty alleviation in the villages, the introduction of rural attractions to all and the introduction 
of villages in the field of tourism and tourism and not only the rural environment They will be influenced by tourist attractions, but all the factors in this section will be influenced by tourist attractions.

Ghasemi and Khodabakhshi (2012) in their article entitled "Study and analysis of rural entrepreneurship development mechanisms (case study: Kangavar city)" The results of the ranking of rural entrepreneurship development mechanisms showed that the granting of lowinterest banking facilities to applicants, Subsidizing the agricultural sector and establishing appropriate support policies in the agricultural sector were ranked highest, respectively. Also, the four factors of support - facility, education - information, motivation and participation in total explained about $60.68 \%$ of the variance of rural entrepreneurship development mechanisms. The development of rural entrepreneurship can solve a significant part of the problems of this sector, which leads to rural development and subsequent national development.

Izadi et al. (2013) in an article entitled "Entrepreneurship and Rural Development, Lessons from Chinese Experiences with Emphasis on Rural Entrepreneurship" has reviewed policies and operational plans for rural entrepreneurship development in China. The studies of this study show that there are several challenges in rural entrepreneurship programs in China and the adoption of appropriate strategies, especially in the last three decades, such as industrialization of rural areas and the provision of educational services, has led to the success of rural entrepreneurship programs. Has been in this country.

Al-Maliki (2013) in his article entitled "Explaining the position of cooperatives (rural, agriculture and rural production) in the success of rural entrepreneurship" concluded that entrepreneurship is not the only way to create jobs and increase the income of villagers, but can Along with other suitable solutions, be the best of them. Existence of continuous support for rural entrepreneurs, development of appropriate contexts (in terms of social, cultural and economic infrastructure) in rural areas, encouragement of rural entrepreneurs, etc. can be from entrepreneurship, a practical solution suitable for rural development goals, ie. Create useful employment, increase income and participation and build self-reliance of the villagers.

Imanloo (2013) in his article entitled "Explaining the role of rural villages and Islamic councils in sustainable development and rural entrepreneurship Case study of Navai village, Valdian village, Khoy city" while explaining the role of rural villages and Islamic councils in sustainable rural development Dehyari and the Islamic Council of the village have dealt with the development of Navai village and the new job opportunities that have been created in this village with their great interaction and have provided the conditions for the development of Navai village.

Armaghan (2013) in his article entitled "Entrepreneurship Management Strategies in Rural Development with Emphasis on Agriculture" have concluded that entrepreneurship in agricultural joint stock companies in search of a single combination of resources, both inside and outside the activity $\neg$ are agricultural. If we consider the basic solution in the fight against the problems and problems of agriculture in the country as the concentration of agricultural lands and finally the formation of agricultural joint stock companies and consider these companies as the strategic axes of agriculture and food products and products of society that need to be addressed. In addition, we will realize its unique role in growth, development and prosperity, and we will understand that ignoring the share of agricultural joint stock companies will have unfortunate costs and consequences.

Khodabandeh Lou et al. (2014) in his article entitled "The role of rural management in entrepreneurship development" has concluded that rural management as a popular and local institutions that manage villages, due to many interactions with villagers and the government They can by policy-making, management, implementation of various educational programs, development of necessary infrastructure, helping to attract financial resources, entrepreneurial 
behavior and attitude, creating cultural and social contexts of entrepreneurship, creating entrepreneurial motivation among villagers and such things. To play a key role in the development of entrepreneurship in rural areas and to provide the basis for the development of rural entrepreneurship.

\section{Methodology}

In this study, the statistical population includes all villages in rural areas of Khalilabad (23 villages with a population of 10,447 households). Considering that according to Cochran's formula, 21 villages should be studied as a sample, so since the difference between the statistical population and the sample population of the two villages is statistical, the statistical population will be examined as a sample. In this regard, according to the total number of households in the sample villages (10447 households) using the Cochran's formula, 370 questionnaires were distributed in the sample villages and completed by the heads of households.

\section{Results}

Table 1. Results of confirmatory factor analysis of questionnaire structures

\begin{tabular}{|c|c|r|r|r|r|}
\hline Hidden variable & $\mathrm{p}$-value & $\begin{array}{r}\mathrm{T} \\
\text { statistics }\end{array}$ & $\begin{array}{r}\text { Standard } \\
\text { deviation }\end{array}$ & $\begin{array}{r}\text { Standardized } \\
\text { coefficient }\end{array}$ & $\begin{array}{r}\text { Observed } \\
\text { variable } \\
\text { symbol }\end{array}$ \\
\hline $\begin{array}{l}\text { Improving rural } \\
\text { performance } \\
\text { Entrepreneurial } \\
\text { infrastructure }\end{array}$ & 000.0 & 315.17 & 056.0 & 792.0 & $\mathrm{~A} 1$ \\
\cline { 2 - 6 } & 000.0 & 739.14 & 061.0 & 805.0 & $\mathrm{~A} 2$ \\
\cline { 2 - 6 } & 000.0 & 315.14 & 062.0 & 72.0 & $\mathrm{~A} 3$ \\
\cline { 2 - 6 } & 000.0 & 65.13 & 064.0 & 689.0 & $\mathrm{~A} 4$ \\
\cline { 2 - 6 } & 000.0 & 043.16 & 062.0 & 772.0 & $\mathrm{~A} 5$ \\
\cline { 2 - 6 } & 000.0 & 809.13 & 061.0 & 682.0 & $\mathrm{~A} 7$ \\
\hline
\end{tabular}

\section{- Test the normality of research variables}

Table 2. Test the normality of research variables

\begin{tabular}{|r|r|r|r|r|r|r|r|}
\hline $\begin{array}{r}\text { Cronbach's } \\
\text { alpha }\end{array}$ & $\begin{array}{r}\text { the } \\
\text { most }\end{array}$ & $\begin{array}{r}\text { The } \\
\text { least }\end{array}$ & $\begin{array}{r}\text { Slenderness } \\
\text { ratio }\end{array}$ & $\begin{array}{r}\text { Skewness } \\
\text { coefficient }\end{array}$ & $\begin{array}{r}\text { Standard } \\
\text { deviation }\end{array}$ & Average & Variable \\
\hline 873.0 & 00.5 & 00.1 & -0.807 & -0.027 & 904.0 & 911.2 & $\begin{array}{r}\text { The } \\
\text { performance of } \\
\text { rural councils } \\
\text { in improving } \\
\text { the } \\
\text { intrepreneurial } \\
\text { infrastructure }\end{array}$ \\
\hline
\end{tabular}

According to the above table, because the Cronbach's alpha value is higher than $70 \%$, it shows that the items of the research tool have a high internal correlation and the research tool has good reliability. The collected data were processed using SPSS software and one-sample T method. A method is used to calculate the internal consistency of a measuring instrument that measures different properties. Cronbach's alpha coefficient is between 0 and 1 . The number 1 shows the maximum correlation and the number 0 shows the lowest correlation. The closer the percentage is to $100 \%$, the more reliable the questionnaire is. We have to say that an alpha coefficient of less 
than $60 \%$ is usually considered weak, an amplitude of $70 \%$ is acceptable and above $80 \%$ is considered good, but the closer the coefficient of confidence is to number one, the better. The overall Cronbach's alpha value in the questionnaire was 0.758 , which is finally acceptable considering the above, which indicates the appropriate reliability of the research questionnaire. Based on the prototype of 50, the Cronbach's alpha level of the questionnaire for its dimensions is listed in the table below. According to the obtained values, the reliability of the questionnaire is evaluated to the desired level.

- General characteristics of respondents

The distribution of respondents according to age groups in the present study was as follows: $32.7 \%$ in the age groups 20 to 29 and $47.8 \%$ in the age group 30-39, 15.4\% 40-49 and $2.7 \% 50$ years and above, their literacy status It shows that $96.5 \%$ of them were literate and $3.5 \%$ of them were illiterate. Their employment status shows that $36.2 \%$ of them were unemployed and $61.9 \%$ of them were employed. And $33 \%$ of people have an entrepreneurial background.

Hypothesis test :

It seems that the performance of rural areas has improved the entrepreneurial infrastructure. This hypothesis can be examined as follows:

H_0: It seems that the performance of rural areas has not improved the entrepreneurial infrastructure (the average of the variable is not more than 3 ).

H_1: It seems that the performance of rural areas has improved the entrepreneurial infrastructure (the average variable is more than 3 ).

In order to compare the average opinions of the respondents regarding the performance of rural areas in order to improve the entrepreneurial infrastructure, the average of this variable was compared using t-test with the number 3 (average), the results of which are also listed in the table below:

Table 3. Results of comparing the mean of the first hypothesis with the number 3 by $t$ test

\begin{tabular}{|l|l|l|l|l|l|l|}
\hline $\begin{array}{l}\text { The result } \\
\text { of the } \\
\text { hypothesis }\end{array}$ & $\begin{array}{l}-\mathrm{p} \\
\text { value }\end{array}$ & $\begin{array}{l}\text { Degrees of } \\
\text { freedom }\end{array}$ & $\begin{array}{l}\text { Statistic } \\
\text { s t }\end{array}$ & $\begin{array}{l}\text { Standard } \\
\text { deviatio } \\
\mathrm{n}\end{array}$ & $\begin{array}{l}\text { Averag } \\
\mathrm{e}\end{array}$ & Survey \\
\hline $\begin{array}{l}\text { disapprova } \\
1\end{array}$ & 059.0 & 368 & -1.895 & 904.0 & 911.2 & $\begin{array}{l}\text { The } \\
\text { performance } \\
\text { of rural } \\
\text { councils in } \\
\text { improving the } \\
\text { entrepreneuria } \\
\text { infrastructure }\end{array}$ \\
\hline
\end{tabular}

Considering the results of the above table, since the average (2.911) is less than 3, so the null hypothesis that the performance of rural areas has not improved the entrepreneurial infrastructure is accepted and the research hypothesis is not confirmed.

\section{Discussion and conclusión}

The effective factor on the development of entrepreneurship in rural areas should be considered in rural management, which can provide an efficient step in the development of entrepreneurship and increase employment in rural areas by developing entrepreneurial infrastructure. In the villages, of course, there are unknown capacities to launch entrepreneurial activities, which the villagers can use to better plan, create jobs and entrepreneurship and achieve the desired result. 
In our country, the Islamic councils of villages and villages are a clear example of handing over the management of villages to its natives. Rural management, especially rural development, provides the ground for the development of rural areas. Therefore, improving the performance of rural areas as a public non-governmental organization as an institution that represents the various units of rural people, is a very effective tool for the development of rural entrepreneurship. Villages can create rural entrepreneurship development in various sectors in terms of developing entrepreneurial infrastructure, improving the social context of entrepreneurship and attracting financial resources.

According to the results obtained in rural areas of the city, satisfaction with the performance of rural areas in improving entrepreneurial infrastructure for entrepreneurship development is less than average, while the performance of rural areas in improving public infrastructure (water, electricity) And ...) In all villages of the city, the situation is average. The results of testing the hypotheses showed that the villagers of Khalilabad city were not successful in the development of rural entrepreneurs and had poor performance.

\section{Issues and problems and provide solutions}

Table 4. Issues and problems and provide solutions

\begin{tabular}{|c|c|}
\hline solutions & issues and problems \\
\hline $\begin{array}{l}\text { Holding training and orientation courses } \\
\text { Establishing communication between villagers } \\
\text { and entrepreneurs }\end{array}$ & $\begin{array}{l}\text { Little familiarity of villagers with the } \\
\text { category of entrepreneurship }\end{array}$ \\
\hline $\begin{array}{l}\text { Improving the transport network } \\
\text { Improving telecommunication network and } \\
\text { internet } \\
\text { Development of infrastructure services such as } \\
\text { water, electricity and... }\end{array}$ & $\begin{array}{l}\text { Lack of necessary infrastructure for } \\
\text { entrepreneurship }\end{array}$ \\
\hline $\begin{array}{l}\text { Facilitating the administrative process and } \\
\text { assisting in this field }\end{array}$ & $\begin{array}{l}\text { Lack of familiarity with the administrative } \\
\text { structure and its complexities }\end{array}$ \\
\hline
\end{tabular}

\section{References}

Azizi Demirchloo Abdullah. (2012). New Rural Management A Strategy for Realizing Rural Entrepreneurship, National Conference on Rural Development, Rasht, University of Guilan.

Behmand Dadaleh. (2015). A Study of the Role of Modern Rural Management in Entrepreneurship Development (Case Study: Firoozabad Villages), International Conference on Architecture, Urban Planning, Civil Engineering, Art and Environment; Future Horizons, Looking to the Past, Tehran, Permanent Secretariat of the Conference.

Haring Lee Lloyd and John Luther and John F. Lonsbury, John W. Fries. (1998). An Introduction to Scientific Research in Geography, translated by Ali Molazadeh, Shahid Chamran of Ahvaz, first edition.

Hashemi Seyed Saeed, Seyed Hassan Motiee Langroudi, Mojtaba Ghadiri Masoom, Mohammad Reza Rezvani, Seyed Mohammad Moghimit. (2011). The Role of Islamic Villages and Councils in Rural Entrepreneurship Development (Case Study: Bahabad, Yazd Province), Journal of Rural Research, Second Year ‘Issue 1, Spring 2011. 
Ismaili Gholam Ali, Ismail Desert. (2002). Research Method on Sanjesh Publications, First Edition.

Khoda Bandeloo Hajar; Mohammad Alizadeh Toli and Rahimeh Bahmani. (2014). The Role of Rural Management in Entrepreneurship Development, International Conference on Sustainable Development, Strategies and Challenges Focusing on Agriculture, Natural Resources, Environment and Tourism, Tabriz, Permanent Secretariat of the International Conference on Sustainable Development, Solutions and challenges.

Kiakjuri Karim; Forough Roodgarnejad and Majid Poureisi. (2012). Presenting a conceptual model of barriers affecting the development of entrepreneurship, National Conference on Rural Development, Rasht, University of Guilan.

Molashahi Gholamabbas, Elena Tabrizi Dokhtofard. (2014). The importance of entrepreneurship and its role in the development of rural communities, Quarterly Journal of Agricultural Engineering and Natural Resources, 44 consecutive, summer 2014.

Najafikani Ali Akbar, Mehdi Hesam, Hadiseh Ashour. (2015). Assessing the status of entrepreneurship development in rural areas Case: South Astarabad rural district in Gorgan, Quarterly Journal of Space Economics and Rural Development, Fourth Year, Issue 1, Spring 2015, Successive 11.

Rahnar Mahnaz, Seyed Alaeddin Alavi. (2012). A Study of the Rural Management Model in Iran with Emphasis on Influential Institutions (Islamic Villages and Councils), National Conference on Rural Development, Rasht, University of Guilan.

Rokn al-Din Eftekhari Abdolreza, Sajasi-Gheidari Hamdaleh. (2014). Rural Development with Emphasis on Entrepreneurship (Definitions, Views and Experiences), Samat Publications.

Saeedi Parviz. (2009). The role of modern rural management in entrepreneurship and job creation in rural areas, Yas 2009 Strategy Quarterly, No. 19.

Sarukhani Mohammad Baqer. (2008). Research Methods in Social Sciences, Institute of Cultural Studies and Research, Volume One.

Tusi Ramadan, Jamshidi Alireza, Taqdisi Ahmad. (2014). Rural Entrepreneurship and Determining the Factors Affecting It (Case Study: Villages of Minoodasht County), Journal of Rural Research and Planning, Volume 3, Number 8, Winter 2014. 